\title{
Editorial Foreword 71.3 (August 2012)
}

\section{Our Cover}

The photo was taken by Rian Thum in May of 2010, at the Shrine of Imam Asim, near Khotan in Xinjiang. It shows a singer of tales (ghăzălchi) alternately chanting lines from a tale and plucking his dutar. He is a member of a threeperson troupe. On the day of this photo, they performed, among other songs and tales, the story of Seyit Nochi, a young man who left home for a local pilgrimage and ended up losing his life by the order of a Qing official. In the background, a crowd gathers around a professional storyteller (qissăkhan), who is telling a story from a hagiography (tăzkiră).

\section{An Overview of the Issue:}

This issue begins with an "Asia Beyond the Headlines" essay that looks back on one of the most talked-about Indian events of 2011: the protests spearheaded by Anna Hazare that garnered a good deal of support, including from members of the country's middle class. Political scientist Mitu SEnguPTA looks at issues associated with this struggle, such as anger over government corruption, that continue to be very important in India, as well as in many other Asian and non-Asian countries. She also seeks to place Hazare's actions, including a high profile hunger strike, into a broadly framed long-term perspective. How, Sengupta asks, did Hazare, a "short, bespectacled, 74 year-old man" rise quickly from relative anonymity to capture the attention of the international media? The answer, she argues, lies in large part in his conscious, strategic and effective use of potent symbols associated with Gandhi. While part of Sengupta's concern is thus with locating Hazare into historical perspective, she ends by offering forward-looking insights. She notes, for example, the challenges ahead for members of "Team Anna," as she dubs Hazare and those close to him, as they strive to "navigate the difficult terrain of contemporary Indian politics, striking a balance between opposing the government," without which it will be unable to garner the necessary support for the anti-corruption legislation it seeks to pass, "and maintaining a semblance of political neutrality, without which it will lose moral authority."

The research articles section of the issue begin with a pair of essays that look at Xinjiang. In the first, "Profit and Protection: Emin Khwaja and the Qing Conquest of Central Asia, 1759-1777," historian of China and Central Asia KwAnGMIN KIM offers a Muslim perspective on the way this territory, which now makes up the northeastern-most section of the People's Republic of China, came under 
the control of Beijing. Drawing on sources and scholarship in several different languages and highlighting economic as well as military and political factors, Kim focuses on the motivations and career of one of the most prominent local collaborators in the take-over of Xinjiang, a man who spent the last years of his life working for the Qing Dynasty (1644-1911) as the supervisor overseeing "conquered Muslim oases" in the frontier zone.

Following Kim’s article comes Rian Thum’s "Modular History: Identity Maintenance before Uyghur Nationalism," which focuses on an important set of inhabitants of Xinjiang in the final decades of the Qing era and for part of China's Republican period (1912-1949). Thum, like Kim a specialist in history, is primarily interested in how a sense of identity was created and maintained among the "Turki-speaking, sedentary, Muslim inhabitants of Altishar" (an indigenous term for what others refer to by various other toponyms, such as Eastern Turkestan, Chinese Turkestan and Southern Xinjiang. Here, again, materials in a wide range of languages are used to bring a story to life and back up arguments, many of which hinge upon a vision of community solidarity fostered by narratives (e.g., of local heroes) and symbolically charged locales and actions (such as travel to interconnected shrines).

In the next article, geographer IAN G. BAIRD’s “Lao Buddhist Monks’ Involvement in Resistance to the Lao People's Democratic Republic Government Since 1975," we are taken to a very different part of Asia. The starting point for the essay, though, is not in Asia at all, but a Buddhist Temple in Edmonton, Canada, where the geographer met with a Lao monk who "periodically sipped on a mango smoothie" during their exchange and told Baird of Communists coming to his village in the 1950 s and killing the local headman. Of special interest to Baird is the way that Lao Buddhist monks, such as the one he met with in Canada, who spent part of his life in war torn areas training medics, have "negotiated religious conduct rules in the context of strong nationalist convictions," figuring out ways to square collaborating with armed rebels with adherence to the non-violent tenets of Lao Buddhism.

The issue ends with a trio of essays that explore different aspects of contemporary China. In the first of these, "Constructing Myth in Modern China," RoBiN MCNEAL, a specialist in early Chinese literature and history, provides an illustrated look at a Wuhan park devoted to "Yu the Great," the legendary sage king known for his ability to conquer floods. McNeal uses this statue-filled park to show how, in the last century or so, various stories and figures from the ancient Chinese past have been recast to share commonalities with those found in Greek and Norse mythology. This is no mere accident, but rather fall-out from efforts by Chinese intellectuals, including the country's first specialists in folklore, to transform tales thought of as simply historical into a more recognizably mythic mode, so that China could be said to have a distinctive mythology.

The second essay in this final trio is anthropologist YunXIAnG Yan's "Food Safety and Social Risk in Contemporary China," which focuses on a subject that has gotten a great deal of attention in the Chinese and international press in recent years: scares relating to poisoned, doctored and otherwise unsafe 
culinary products, including pork and powdered milk. In an essay that has some of the features associated with "Asia Beyond the Headlines" contributions, but takes the form as a full-length and extensively documented research article, Yan builds on work by theorists such as Ulrich Beck and Anthony Giddens that highlight the very different ways that risk is assessed and thought about in modern societies as opposed to in other contexts. What makes the Chinese case so fascinating, he argues, is that fears relating to food are playing out at time when the country is rocketing so quickly from being "a largely pre-industrial to a largely post-industrial" state.

The issue ends with "Constructing Commonality: Standardization and Modernization in Chinese Nation-Building," in which ANDREW B. KIPNIS, who is also an anthropologist, looks at the places and practices that knit the PRC together as an imagined community. Kipnis argues that, due in part to the recent emphasis put on globalization and concern with the ways that China is "opening up to the outside world," nation-building of the sort he has in mind has been getting too little attention. He offers a correction to this via discussion of three arenas: "the consolidation of the education system, the expansion of the urban built environment and the spread of the Chinese Internet." Each in its own way, Kipnis insists, has helped "result in an increased degree of commonality in lived experience and communicative practice across China.”

\title{
Forthcoming Articles in JAS 71:4 (November 2012)
}

\author{
Asia Beyond the Headlines
}

Lessons from the Ghost of Salaryman Past: The Global Costs of a Breadwinner Imaginary

Robin LEBLANC

\section{Trends}

Gender, Sexuality, and the State in Southeast Asia

Michael G. Peletz

Presidential Address

Disquiet in the House of Gender

Gail Hershatter

JAS at AAS Round Table: Sexuality and the State 
The Nation-State, The Age/Gender System, And The Reconstitution Of Erotic Desire In Nineteenth-Century Japan

Gregory M. Pflugfelder

Popular Culture and Masculinity Ideals in East Asia, with Special Reference to China

Kam Louie

When 'Sexuality' Floated Free of Histories in South Asia INDRANi ChatTERJEE

Age as a Category of Gender Analysis: Servant Girls, Modern Girls and Gender in Southeast Asia

RACHEL LEOW

Comments on the JAS at AAS Round Table: Sexuality and the State Elizabeth Remick

Research Articles

Writing for Justice: An Activist Beginning of the Cult of Female Chastity in Late Imperial China

SIYEN FEI

At the Margins of Empire: Feminist-Nationalist Configurations of Burmese Society in the Hindi Public (1917-1920)

SHObNa NijHaWAN

Marriage Mobility and Footbinding in Pre-1949 Rural China: A Reconsideration of Gender, Economics and Meaning in Social Causation Melissa J. Brown, Laurel Bossen, Hill Gates, Damian SATterthwaite-Phillips

Gender, Uyghur Identity, and the Story of Nuzugum KARA ABRAMSON 